\title{
Fertilizing ability in vivo and in vitro of spermatozoa of rats and mice treated with $\alpha$-chlorohydrin
}

\author{
Y. Tsunoda and M. C. Chang \\ Worcester Foundation for Experimental Biology, Shrewsbury, Massachusetts 01545, U.S.A.
}

\begin{abstract}
Summary. The fertilizing ability of epididymal spermatozoa from rats and mice treated for 3 or 4 or 9 or 10 days with various doses of $\alpha$-chlorohydrin was tested in vitro, and in vivo by intrauterine insemination. The minimum doses (per $\mathrm{kg} / \mathrm{day}$ ) needed to affect fertilization significantly were: rat, in vitro, $8.8 \mathrm{mg}$ for 3 or 4 days, $4.4 \mathrm{mg}$ for 4 days and $2.7 \mathrm{mg}$ for 9 or 10 days; in vivo, $4.4 \mathrm{mg}$ for 3 or 4 days and $2.7 \mathrm{mg}$ for 9 or 10 days: mouse, in vitro, $4.4 \mathrm{mg}$ for 3 days and $13.3 \mathrm{mg}$ for 9 days; in vivo, $44.2 \mathrm{mg}$ for 3 days and 26.5 for 9 days. Rats were infertile for at least 18 days after receiving $44.2 \mathrm{mg} \alpha$-chlorohydrin $/ \mathrm{kg} /$ day for 3 days, but fertilizing ability, tested in vivo and in vitro, was restored 10-11 days and 15-18 days, respectively, after daily treatment with $11 \cdot 1 \mathrm{mg} \alpha$-chlorohydrin $/ \mathrm{kg}$ for 3 days.
\end{abstract}

\section{Introduction}

Administration of $\alpha$-chlorohydrin (3-chlor-1,2 propanediol) does not impair mating ability but does induce temporary or permanent sterility in the male rat (Ericsson, 1970; Banik, Tanikella \& Rakhit, 1972; Cooper, Jones \& Jackson, 1974) and in the males of several other species. The drug does not, however, cause sterility in the male mouse (Samojlik \& Chang, 1970). Ericsson (1970) observed no effect on rat sperm motility, but Coppola (1969) and Samojlik \& Chang (1970) found that $\alpha$-chlorohydrin inhibited the motility of rat epididymal spermatozoa.

Successful fertilization of mouse (Whittingham, 1968) and rat (Miyamoto \& Chang, 1973) eggs in vitro was first achieved by incubating freshly ovulated eggs with capacitated spermatozoa recovered from the uterus of mated animals. The fertilization of mouse and rat eggs by epididymal spermatozoa in vitro is now a routine procedure (Iwamatsu \& Chang, 1970; Toyoda, Yokoyama \& Hosi, 1971; Niwa \& Chang, 1973, 1974b; Toyoda \& Chang, 1974; Tsunoda \& Chang, 1975).

In the present study the effective doses and the duration of infertility following daily treatment of male rats and mice with various doses of $\alpha$-chlorohydrin were examined to determine whether the technique of in-vitro fertilization is valid for testing the fertilizing capacity of epididymal spermatozoa. The fertilizing capacity of the spermatozoa was also tested in vivo for comparison.

\section{Materials and Methods}

\section{Treatment of males}

Mature male rats (354-700 g) of the CD strain descended from Sprague-Dawley stock and mature CD-1 Swiss albino male mice (30-45 g) were housed in a light- and temperature-controlled room. Alpha-chlorohydrin (density 1.326; Upjohn Co.) was diluted with $0.9 \% \mathrm{NaCl}$ solution to the desired concentration, and the drug was injected i.p. in $0.05 \mathrm{ml} / 100 \mathrm{~g}$ body weight for the rat and in $0.4 \mathrm{ml} / 100 \mathrm{~g}$ for the mouse; control animals received the same volume of $0.9 \% \mathrm{NaCl}$ solution. After three daily injections, one testis +epididymis was removed and the fertilizing capacity of spermatozoa from the cauda epididymidis was tested in vitro and/or in vivo. On the 4th day, the animals were killed and the viability of the spermatozoa was tested. In additional groups, one testis was removed on the 9th day of treatment and the animals were killed next day. Body weights and those of the testes and epididymides were recorded. 
To investigate the duration of effectiveness of $\alpha$-chlorohydrin after treatment, male rats were injected with effective doses (see Table 3 ) for 3 days and killed on various subsequent days to test fertilizing ability of spermatozoa in vitro and in vivo.

\section{In-vitro fertilization}

A modified Krebs-Ringer bicarbonate solution containing crystalline bovine serum albumin $(4 \mathrm{mg} / \mathrm{ml})$ and antibiotics was prepared by the method of Toyoda et al. (1971) for mouse gametes and of Toyoda \& Chang (1974) for rat gametes.

Spermatozoa were obtained from the cauda epididymidis. A drop of the sperm mass was suspended in $0.5 \mathrm{ml}$ culture medium, and covered with paraffin oil (Saybolt, viscosity 125/135; Fisher Scientific Co.), previously equilibrated with $5 \% \mathrm{CO}_{2}$ in air, in a Falcon plastic dish. After 10 min $0.03-0.05 \mathrm{ml}$ sperm suspension was placed in $0.4 \mathrm{ml}$ of the same medium and covered with paraffin oil. The sperm concentrations were $0.02-0.82 \times 10^{6} \mathrm{cells} / \mathrm{ml}$ for the rat and $0.01-0.77 \times 10^{6} \mathrm{cell} / \mathrm{s} / \mathrm{ml}$ for the mouse. The spermatozoa were preincubated for $4-6 \mathrm{hr}$ and $1 \mathrm{hr}$, respectively, in $5 \% \mathrm{CO}_{2}$ in air at $37^{\circ} \mathrm{C}$ before introduction of the eggs.

Immature $C D$ female rats (19-28 days old) and mature CD-1 female mice (21-30 g) were induced to superovulate by treatment with PMSG and HCG and were killed 14-18 hr after injection of HCG. Oviducal eggs were recovered, added to the preincubated sperm suspensions and incubated at $37^{\circ} \mathrm{C}$ in $5 \% \mathrm{CO}_{2}$ in air. The eggs were removed after incubation for $4-8 \mathrm{hr}$, mounted in toto, stained with $0.25 \%$ lacmoid (Chang, 1952) and examined for evidence of sperm penetration or fertilization. Sperm motility was examined at the time of preparation of the sperm suspension and at the times of introduction and examination of eggs.

\section{In-vivo fertilization}

Spermatozoa from the same male were often used for in-vitro and in-vivo fertilization, but sperm concentrations were higher for the latter, being $2 \cdot 6-41 \times 10^{6}$ cells $/ \mathrm{ml}$. Superovulating immature rats and mature mice were anaesthetized with ether or sodium pentobarbital 11-16 hr after the HCG injection and the uteri exposed. The sperm suspension $(0.05 \mathrm{ml})$ was injected into the lumen of each uterine horn through a 25 -gauge needle. Different sperm suspensions were frequently injected into each uterine horn of the same female, but the horns were ligated to prevent the mixing of the samples. Most females were killed 23-24 hr after insemination but a few mice were killed 8-12 hr later. The eggs were flushed from the oviducts, mounted in toto, stained and examined for evidence of fertilization.

In each experiment, fertilizing capacity of spermatozoa was expressed in terms of the percentage of eggs fertilized. The term 'fertilized eggs' denotes all eggs penetrated by one or more spermatozoa. This includes the eggs with supplementary spermatozoa in the perivitelline space (very few), those with an enlarged sperm head or male pronucleus with corresponding sperm tail (many) and those that had cleaved and had a sperm tail (very few). Statistical significance was determined by the $\chi^{2}$ test.

\section{Results}

\section{Rats (Table 1)}

In-vitro tests. Doses of $\geqslant 11 \cdot 1 \mathrm{mg} \alpha$-chlorohydrin $/ \mathrm{kg} /$ day for 3 or 4 days completely inhibited the fertilizing capacity of spermatozoa. At a dose of $4.4 \mathrm{mg} \alpha$-chlorohydrin $/ \mathrm{kg} /$ day for 3 days the fertilizing capacity of spermatozoa was similar to that of controls although significantly lower after 4 days of treatment. At the $8.8 \mathrm{mg}$ dose the fertilizing capacity of spermatozoa was significantly reduced after 3 days and lower still after 4 days. After treatment with $\alpha$-chlorohydrin for 9 and 10 days, complete inhibition of fertilization required only $4 \cdot 4 \mathrm{mg} / \mathrm{kg} /$ day. 
Table 1. Fertilizing capacity in vitro and in vivo (see text) of epididymal spermatozoa from male rats treated with various doses of $\alpha$-chlorohydrin

\begin{tabular}{|c|c|c|c|c|}
\hline $\begin{array}{l}\text { Dose of } \\
\alpha \text {-chlorohydrin } \\
\text { (mg/kg) }\end{array}$ & $\begin{array}{l}\text { Duration of } \\
\text { treatment } \\
\text { (days) }\end{array}$ & $\begin{array}{l}\text { No. of } \\
\text { males } \\
\text { treated }\end{array}$ & $\begin{array}{l}\text { No. of } \\
\text { females } \\
\text { used } f\end{array}$ & $\begin{array}{l}\text { No. of eggs fertilized } \\
\text { no. of eggs examined } \\
(\%)\end{array}$ \\
\hline \multicolumn{5}{|l|}{ In vitro } \\
\hline \multicolumn{5}{|l|}{$44 \cdot 2,22 \cdot 1$} \\
\hline $14 \cdot 7,11 \cdot 1$ & 3,4 & 20 & & $0 / 847 \quad(0)^{* *}$ \\
\hline \multirow[t]{2}{*}{$8 \cdot 8$} & 3 & 6 & & $73 / 240(30)^{* *}$ \\
\hline & 4 & & & $16 / 205 \quad(8)^{* *}$ \\
\hline \multirow[t]{2}{*}{$4 \cdot 4$} & 3 & 6 & & $116 / 167(69)$ \\
\hline & 4 & & & $113 / 219(52)^{*}$ \\
\hline 0 (control) & 3,4 & 10 & & $236 / 339(70)$ \\
\hline $13 \cdot 3,6 \cdot 6,4 \cdot 4$ & 9,10 & 9 & & $0 / 430 \quad(0)$ \\
\hline $2 \cdot 7$ & 9,10 & 3 & & $35 / 89 \quad(39)^{* *}$ \\
\hline $1 \cdot 3$ & 9,10 & 2 & & $81 / 92 \quad(88)$ \\
\hline 0 (control) & 9,10 & 9 & & $213 / 280(76)$ \\
\hline \multicolumn{5}{|l|}{ In vivo } \\
\hline $44 \cdot 2,22 \cdot 1$ & 3,4 & 4 & $12(0)$ & $0 / 237 \quad(0)^{* *}$ \\
\hline $14 \cdot 7$ & 3,4 & 2 & 10 (1) & $17 / 218 \quad(8)^{* *}$ \\
\hline $11 \cdot 1$ & 3,4 & 2 & 11 (2) & $15 / 173(9)^{* *}$ \\
\hline $8 \cdot 8$ & 3,4 & 2 & 11 (1) & $9 / 153 \quad(6)^{* *}$ \\
\hline $4 \cdot 4$ & 3,4 & 2 & $12(9)$ & $44 / 189(23)^{* *}$ \\
\hline 0 (control) & 3,4 & 6 & 17 (17) & $183 / 228(80)$ \\
\hline \multicolumn{5}{|l|}{$13 \cdot 3,6 \cdot 6$} \\
\hline $4 \cdot 4,2 \cdot 7$ & 9,10 & 8 & $20 \quad(0)$ & $0 / 331 \quad(0)^{* *}$ \\
\hline $1 \cdot 3$ & 9,10 & 2 & 4 (4) & $63 / 101(62)$ \\
\hline 0 (control) & 9,10 & 3 & $13(13)$ & $143 / 208(69)$ \\
\hline
\end{tabular}

Significantly different from the respective control values, ${ }^{*} P<0 \cdot 01$; ${ }^{* *} P<0 \cdot 001$. $\dagger$ Figures in parentheses denote the number of females which had fertilized eggs.

In-vivo tests. There was significant inhibition of fertilization with all the doses tested for 3 or 4 days. Fertilizing capacity was not affected after treatment with $1.3 \mathrm{mg}$ for 9 or 10 days compared with controls, but it was significantly lower $(P<0.01)$ than that obtained in the in-vitro tests.

\section{Mice (Table 2)}

In-vitro tests. Doses of 53 to $353.6 \mathrm{mg} \alpha$-chlorohydrin $/ \mathrm{kg} /$ day for 3-9 days were lethal, especially those above $66 \mathrm{mg} / \mathrm{kg}$. Fertilizing capacity was significantly reduced after treatment with the lower doses. After treatment for 9 days, fertilization rates were not affected by doses of 1.3 or $2.7 \mathrm{mg} / \mathrm{kg}$. Thus, the minimum effective dose was about $4.4 \mathrm{mg} / \mathrm{kg} /$ day for 3 days and about $13.3 \mathrm{mg}$ $\alpha$-chlorohydrin $/ \mathrm{kg} /$ day for 9 days.

In-vivo tests. The minimum effective treatments were $44 \cdot 2 \mathrm{mg} / \mathrm{kg} /$ day for 3 days and $26.5 \mathrm{mg}$ for 9 days. At the dose level of $44.2 \mathrm{mg} / \mathrm{kg}$ for 3 days there was a significant difference in the number of eggs fertilized in vivo and in vitro. The effective dose for inhibition of fertilization in vivo was higher than that required to produce the same effect in vitro.

\section{Recovery of fertilizing capacity of rat spermatozoa after treatment}

Sperm motility was poor after treatment with $44.2 \mathrm{mg} \alpha$-chlorohydrin/ $\mathrm{kg} /$ day and none of the eggs was fertilized in vitro or in vivo 11-15 days after the withdrawal of treatment. Spermatozoa were still immotile 15-18 days after the end of treatment and further tests were not conducted. At a dose level of $11 \cdot 1 \mathrm{mg}$ for 3 days none of the eggs was fertilized in vitro 1-11 days after the end of treatment but 0 to $64 \%$ eggs were fertilized in vivo by spermatozoa obtained 1 to 18 days, respectively, after cessation of the drug. No fertilization occurred in vitro, but $66 \%$ of eggs were fertilized in vivo 10 or 11 days after the end of treatment with this dose. Fertilization again seemed to occur more readily in vivo than in vitro. 
Table 2. Fertilizing capacity in vitro and in vivo (see text) of epididymal spermatozoa from male mice treated with various doses of $\alpha$-chlorohydrin

\begin{tabular}{|c|c|c|c|c|c|}
\hline \multirow[t]{2}{*}{$\begin{array}{l}\text { Dose of } \\
\alpha \text {-chlorohydrin } \\
(\mathrm{mg} / \mathrm{kg})\end{array}$} & \multirow[t]{2}{*}{$\begin{array}{l}\text { Duration of } \\
\text { treatment } \\
\text { (days) }\end{array}$} & \multirow[t]{2}{*}{$\begin{array}{l}\text { No. of } \\
\text { males } \\
\text { treated }\end{array}$} & \multirow[t]{2}{*}{$\begin{array}{l}\text { No. of } \\
\text { females } \\
\text { used } \dagger\end{array}$} & \multicolumn{2}{|c|}{$\begin{array}{l}\text { No. of eggs fertilized/ } \\
\text { no. of eggs examined } \\
(\%)\end{array}$} \\
\hline & & & & & \\
\hline $353 \cdot 6,176 \cdot 8$, & & & & & \\
\hline $\begin{array}{l}132 \cdot 6 \\
88 \cdot 4\end{array}$ & $\begin{array}{l}3 \\
3\end{array}$ & $\begin{array}{l}9 \ddagger \\
2\end{array}$ & & $\begin{array}{l}0 / 133 \\
1 / 33\end{array}$ & $\begin{array}{l}(0)^{* *} \\
(3)^{* *}\end{array}$ \\
\hline $44 \cdot 2$ & 3 & 12 & & $86 / 349$ & $(25)^{* *}$ \\
\hline $8 \cdot 8$ & 3 & 8 & & $60 / 102$ & (59) \\
\hline $4 \cdot 4$ & 3 & 9 & & $42 / 79$ & $(53)^{*}$ \\
\hline 0 (control) & 3 & 15 & & $283 / 407$ & (70) \\
\hline $106 \cdot 1,92 \cdot 8$ & & & & & \\
\hline $79 \cdot 6,66 \cdot 3$ & 9 & $8 \ddagger$ & & $0 / 16$ & $(0)^{* *}$ \\
\hline 53 & 9 & $6 \ddagger$ & & $28 / 118$ & $(20)^{* *}$ \\
\hline $26 \cdot 5$ & 9 & 9 & & $53 / 112$ & $(48)^{* *}$ \\
\hline $13 \cdot 3$ & 9 & 9 & & $68 / 159$ & $(43)^{* *}$ \\
\hline $2 \cdot 7$ & 9 & 7 & & $72 / 105$ & (69) \\
\hline $1 \cdot 3$ & 9 & 5 & & $90 / 122$ & (74) \\
\hline 0 (control) & 9 & 10 & & $175 / 219$ & $(80)$ \\
\hline \multicolumn{6}{|l|}{ In vivo } \\
\hline $132 \cdot 6$ & 3 & 2 & $3(2)$ & $10 / 35$ & $(29)^{* *}$ \\
\hline $88 \cdot 4$ & 3 & 2 & $3(3)$ & $20 / 42$ & $(48)^{* *}$ \\
\hline $44 \cdot 2$ & 3 & 2 & 3 (2) & $17 / 30$ & $(57)^{* *}$ \\
\hline $8 \cdot 8$ & 3 & 2 & $4(4)$ & $42 / 42$ & (100) \\
\hline 0 (control) & 3 & 6 & 7 (7) & $102 / 111$ & (92) \\
\hline $26 \cdot 5$ & 9 & 2 & $3(2)$ & $19 / 42$ & $(46)^{* *}$ \\
\hline $13 \cdot 3$ & 9 & 2 & $3(3)$ & $51 / 53$ & (96) \\
\hline $2 \cdot 7$ & 9 & 2 & $2(2)$ & $27 / 27$ & (100) \\
\hline 0 (control) & 9 & 5 & $4(4)$ & $43 / 48$ & (90) \\
\hline
\end{tabular}

Significantly different from the respective controls, ${ }^{*} P<0.01 ;{ }^{* *} P<0 \cdot 001$.

$\dagger$ Figures in parentheses denote the number of females which had fertilized eggs.

$\ddagger$ Fourteen of twenty-three mice died during treatment.

\section{Motility of spermatozoa}

At the time of dilution rat spermatozoa usually showed good motility in the control sample, irrespective of the dosage and duration of treatment with $\alpha$-chlorohydrin. However, after incubation for 4-6 hr, sperm motility decreased conspicuously, especially in the sperm samples from rats treated with more than 11.1 or $4.4 \mathrm{mg} \alpha$-chlorohydrin/ $/ \mathrm{kg} /$ day for 3-4 days or 9-10 days, respectively. At the time of examination of the eggs (about 8-14 hr after incubation) motility decreased slightly in the control samples and no motility was observed in the sperm samples from rats treated with a high dose of $\alpha$-chlorohydrin. The motility of mouse spermatozoa at the time of dilution was quite good, except in the sperm samples from animals treated with $176.8 \mathrm{mg} \alpha$-chlorohydrin $/ \mathrm{kg} /$ day for 3 days, in which motility was poor or absent. After incubation for $1 \mathrm{hr}$ and at the end of incubation with eggs, the motility of spermatozoa from control mice was quite good, whereas spermatozoa from the animals treated with $>44.2 \mathrm{mg} \alpha$-chlorohydrin $/ \mathrm{kg} /$ day for 3 days and from those treated with $>26.5 \mathrm{mg} \alpha$-chlorohydrin $/ \mathrm{kg} /$ day for 9 days was very poor.

\section{Effects on body weight, and testistepididymis weight}

Body weight decreased slightly after treatment of rats with $\alpha$-chlorohydrin for 3 or 4 days but did not decrease after treatment for 9 or 10 days. The weights of the testes and epididymides in rats were not affected, irrespective of the dosage and the duration of treatment. In the mouse, body weight decreased in animals treated with $>\mathbf{4 4 . 2} \mathrm{mg} \alpha$-chlorohydrin/ $\mathrm{kg} /$ day for 3 days and in those treated 
with $53.0 \mathrm{mg} / \mathrm{kg}$ for 9 days. There was some decrease in testis weight in mice, especially after treatment with 4.4-176.8 $\mathrm{mg} \alpha$-chlorohydrin $/ \mathrm{kg} /$ day for 3 days.

\section{Discussion}

Male sterility can be caused by impairment of various functions, such as suppression of spermatogenesis, mating ability, ejaculation, or inhibition of the motility and metabolism of spermatozoa or their fertilizing capacity. This study confirms the observations of Ericsson \& Baker (1970), Turner (1971) and Lubicz-Nawrocki \& Chang (1974a, b) that $\alpha$-chlorohydrin causes infertility by inhibiting the fertilizing capacity of spermatozoa in the cauda epididymidis, although the effectiveness of the drug varies with the dosage, duration of treatment, species, and the testing system. Vickery, Erickson $\&$ Bennett (1974) reported that sterility occurs in Sprague-Dawley male rats after administration of $10 \mathrm{mg} \alpha$-chlorohydrin $/ \mathrm{kg} /$ day for 3 days or $2.5 \mathrm{mg} / \mathrm{kg} /$ day for 9 days and suggested that $\alpha$-chlorohydrin caused sterility by inhibiting sperm transport through a change in the constituents of seminal plasma. The present experiment, however, clearly demonstrates that the major effect is on the fertilizing capacity of spermatozoa.

It is known that capacitation of mouse spermatozoa in vitro takes approximately $1 \mathrm{hr}$ (Toyoda et al., 1971) while rat spermatozoa require 5-6 hr (Niwa \& Chang, 1974a). At the time of introduction of the eggs $1 \mathrm{hr}$ after incubation of mouse spermatozoa and 4-6 hr after incubation of rat spermatozoa (i.e. when the spermatozoa were assumed to have become capacitated), the motility of mouse spermatozoa was generally better than that of rat spermatozoa. The different effects of $\alpha$-chlorohydrin in these two species may therefore be related to the time required for sperm capacitation.

Samojlik \& Chang (1970) reported that fertility was unaffected in male mice receiving 15 or $30 \mathrm{mg} \alpha$-chlorohydrin $/ \mathrm{kg} / \mathrm{day}$. By contrast, the present study has shown that $\alpha$-chlorohydrin inhibited fertilizing capacity of mouse spermatozoa in vitro even with a dose as low as $4.4 \mathrm{mg}$, but $44.2 \mathrm{mg}$ was required to inhibit fertilization in the in-vivo tests. Fertilization in vitro was completely suppressed by the treatment of mice with more than $88.4 \mathrm{mg} \alpha$-chlorohydrin $/ \mathrm{kg} /$ day for 3 days or $66.3 \mathrm{mg} / \mathrm{kg}$ for 9 days, but such doses were almost lethal and affected physical condition and behaviour as described by Samojlik \& Chang (1970) and Johnson \& Pursel (1972).

The present study shows that the fertilizing capacity of spermatozoa from males treated with $\alpha$-chlorohydrin can be tested in vitro. This system is, however, relatively more laborious than testing by uterine insemination and it seems preferable to continue to use the in-vivo test system since this represents a more physiological situation and appears to be more sensitive, at least for the rat.

This work was supported by grants from the National Institute of Child Health and Human Development (HD 03472), the Ford Foundation and the Human Reproduction Unit, World Health Organization. We thank Mrs Rose Bartke for assistance.

\section{References}

BaniK, U.K., TANIKella, T. \& RakhIT, S. (1972) OraI antifertility effects of halo propanediol derivatives in male rats. J. Reprod. Fert. 30, 117-124.

Chang, M.C. (1952) Fertilizability of rabbit ova and the effects of temperature in vitro on their subsequent fertilization and activation in vivo. J. exp. Zool. $121,351-382$.

Cooper, E.R.A., Jones, A.R. \& JACKson, H. (1974) Effects of $\alpha$-chlorohydrin and related compounds on the reproductive organs and fertility of the male rat. J. Reprod. Fert. 38, 379-386.
CoppolA, J.A. (1969) An extragonadal male antifertility agent. Life Sci. 8, 43-48.

Ericsson, R.J. (1970) Male antifertility compounds: U-5897 as a rat chemosterilant. J. Reprod. Fert. 22, 213-222.

ERICSSON, R.J. \& BAKER, V.F. (1970) Male antifertility compounds: biological properties of U-5897 and U-15,646. J. Reprod. Fert. 21, 267-273.

Iwamatsu, T. \& Chang, M.C. (1970) Further investigation of capacitation of sperm and fertilization of mouse eggs in vitro. J. exp. Zool. 175, 271-282. 
Johnson, L.A. \& Pursel, V.G. (1972) Reversible infertility in male swine fed $\alpha$-chlorohydrin. J. Anim. Sci. 34, 241-245.

Lubicz-NAWrocki, C.M. \& Chang, M.C. (1974a) Effect of $\alpha$-chlorohydrin on the fertilizing ability of hamster epididymal spermatozoa. J. Reprod. Fert. 38, 65-71.

Lubicz-Nawrocki, C.M. \& Chang, M.C. (1974b) The onset and duration of infertility in hamsters treated with $\alpha$-chlorohydrin. J. Reprod. Fert. 39, 291-295.

Miyamoto, H. \& Chang, M.C. (1973) In vitro fertilization of rat eggs. Nature, Lond. 241, 50-52.

Niwa, K. \& Chang, M.C. (1973) In-vitro fertilization of rat eggs as affected by the maturity of the females and the concentration of spermatozoa. $J$. Reprod. Fert. $35,577-580$.

Niwa, K. \& Chang, M.C. (1974a) Optimal sperm concentration and minimal number of spermatozoa for fertilization in vitro of rat eggs. J. Reprod. Fert. 40, 471-474.

Niwa, K. \& Chang, M.C. (1974b) Various conditions for the fertilization of rat eggs in vitro. Biol. Reprod. 11, 463-469.
Samojlik, E. \& Chang, M.C. (1970) Antifertility activity of 3-chloro-1,2-propanediol (U-5897) in male rats. Biol. Reprod. 2, 299-304.

Toyoda, Y. \& Chang, M.C. (1974) Fertilization of rat eggs in vitro by epididymal spermatozoa and the development of such eggs following transfer. $J$. Reprod. Fert. 36, 9-22.

Toyoda, Y., Yokoyama, M. \& Hosi, T. (1971) Studies on the fertilization of mouse eggs in vitro. I. In vitro fertilization of eggs by fresh epididymal sperm. Jap. J. Anim. Reprod. 16, 147-151.

TsUNODA, Y. \& CHANG, M.C. (1975) In vitro fertilization of rat and mouse eggs by ejaculated sperm and the effect of energy sources on in vitro fertilization of rat eggs. $J$. exp. Zool. 193, 79-86.

TURner, M.A. (1971) Effects of $\alpha$-chlorohydrin upon the fertility of spermatozoa of the cauda epididymidis of the rat. $J$. Reprod. Fert. 24, 267-269.

VickeRY, B.H., ERICKSON, G.I. \& BENNETT, J.P. (1974) Mechanism of antifertility action of low doses of $\alpha$-chlorohydrin in the male rat. J. Reprod. Fert. 38, 1-10.

WhittinghaM, D.G. (1968) Fertilization of mouse eggs in vitro. Nature, Lond. 220, 592-593.

Received 10 October 1975 